\title{
Effect of Vitamin D on Aldose Reductase in Indonesian Diabetic Polyneuropathy Patients: A Randomized Clinical Trial
}

\author{
(Kesan Vitamin D kepada Aldosa Reduktase dalam Kalangan Pesakit Polineuropati Diabetes Indonesia: Suatu Ujian
} Klinikal Rambang)

\author{
AidA Fitri*, HASAN SJAHRIR, ADANG BACHTIAR \& MUHAMMAD ICHWAN
}

\author{
ABSTRACT
}

Aldose Reductase (AR) is an important factor in the pathogenesis of several Diabetes Mellitus (DM) complications, including diabetic neuropathy $(D N)$. Vitamin D has a direct effect on the pathogenesis of DN. Aldose reductase inhibition is an important element in the prevention of DM complications. The objective of this paper was to assess the effect of vitamin D on AR in Indonesian diabetic polyneuropathy (DPN) patients. This cohort study was undertaken at Haji Adam Malik General Hospital Medan, North Sumatera, Indonesia. In a double-blind, placebo-controlled, clinical trial, eligible patients were randomized to receive vitamin D 50,000 IU/week or placebo for 10 weeks. The primary end-point was mean changes of nerve conduction velocity (NCV) from baseline and after 10 weeks of supplementation. There was no significant correlation between mean changes of vitamin $D$ and AR levels. There was significant correlation with negative direction and weak strength between mean changes of AR level and NCV of motor Tibial nerve ( $p<0.05$; $r=-0.337)$. There was significant correlation with positive direction and moderate strength between mean changes of vitamin D level and NCV of motor Median and Peroneal nerves, and motor and sensory Ulnar nerves $(p \leq 0.001 ; r=0.438$ - 0.527). In conclusion, vitamin D supplementation had no effect on AR level in Indonesian DPN patients. Higher AR level was correlated with decreased NCV of motor Tibial nerve. Vitamin D supplementation improved NCV in DPN.

Keywords: Aldose reductase; diabetic polyneuropathy; nerve conduction velocity; vitamin D

\section{ABSTRAK}

Aldosa Reduktase (AR) merupakan faktor penting dalam patogenesis beberapa komplikasi Diabetes Mellitus (DM), termasuk neuropati diabetes (ND). Vitamin D mempunyai kesan langsung kepada patogenesis ND. Perencatan AR merupakan unsur penting dalam pencegahan komplikasi DM. Tujuan kajian ini dijalankan adalah untuk menilai kesan vitamin D pada AR dalam pesakit polineuropati diabetes (PND) Indonesia. Kajian kohort ini dilakukan di Hospital Umum Haji Adam Malik Medan, Sumatera Utara, Indonesia. Dalam percubaan klinikal gelap ganda, plasebo terkawal, pesakit yang layak menerima vitamin D 50.000 IU/minggu atau plasebo selama 10 minggu secara rambang. Titik akhir utama adalah perubahan purata laju konduksi saraf daripada garis dasar dan selepas 10 minggu penambahan. Tiada korelasi yang signifikan antara perubahan purata tahap vitamin D dengan AR. Terdapat korelasi yang signifikan dengan arah negatif dan kekuatan lemah antara perubahan purata tahap AR dengan laju konduksi saraf motor Tibial $(p<0,05 ; r=-0,337)$. Terdapat korelasi yang signifikan dengan arah positif dan kekuatan sederhana antara perubahan purata tahap vitamin D dengan laju konduksi saraf motor Median dan Peroneal, dan saraf motor dan sensori Ulnar $(p \leq 0,001 ; r=0.438-0.527)$. Secara kesimpulannya, penambahan vitamin $D$ tidak mempunyai kesan pada tahap AR dalam kalangan pesakit PND Indonesia. Tahap AR yang tinggi dikaitkan dengan penurunan laju konduksi saraf motor Tibial. Penambahan vitamin D menambah baik laju konduksi saraf pada PND.

Kata kunci: Aldosa reduktase; laju konduksi saraf; polineuropati diabetes; vitamin D

\section{INTRODUCTION}

The polyol pathway is the most important mechanism in the pathogenesis of Diabetes Mellitus (DM) complications (Santos et al. 2017; Zhu 2013). Aldose reductase (AR) is the main enzyme in the polyol pathway (Zhu 2013). In cell cultures under high glucose conditions, several studies have shown that AR increases the production of reactive oxygen species (ROS), which confirms AR is important 
factor in the pathogenesis of several DM complications, including diabetic neuropathy (DN) (Tang et al. 2012). Aldose Reductase activity is higher in DM patients with neuropathy compared to patients without neuropathy or normal people (Gupta et al. 2017). The discovery of vitamin $\mathrm{D}$ receptors on pancreatic $\beta$ cells directs the role of vitamin $\mathrm{D}$ in the pathogenesis of type $2 \mathrm{DM}$ (T2DM) and its involvement in the development of microvascular complications (Yan \& Khalil 2017).

The polyol pathway and the formation of advanced glycation end-products (AGE) produce large amounts of oxidants and AR inhibitors suppress oxidative nerve tissue (Oyenihi et al. 2015; Ramana 2011). Interventional therapy to increase vitamin $D$ levels and reduce oxidative stress should be included as part of treatment for newly diagnosed DM (Kumar et al. 2017).

The most common diabetic neuropathy is chronic diabetic polyneuropathy (DPN), estimated to be around $75 \%$ of DN (Pop-Busui et al. 2017). Nerve conduction velocity (NCV) is considered the standard for DPN diagnosis (Shekharappa et al. 2011). If neuropathy occurs, the NCV decreases (Kawano 2014). The severity of neuropathy can also be found through the NCV examination (Kakrani et al. 2014). This study aimed to assess the effect of vitamin D on AR in Indonesian DPN patients.

\section{MATERIALS AND METHODS}

Patients suffering from DPN were enrolled from the Department of Neurology, Faculty of Medicine, Universitas Sumatera Utara/Haji Adam Malik General Hospital after the authorized Ethics Committee gave consent (No. 406/TGL/KEPK FK USU-RSUP HAM 2018; June 7th, 2018). Written consent was obtained from all patients participating in the study. All subjects were enrolled in this cohort study between July 2018 and January 2019. The sample size was calculated using the $\mathrm{G}$ Power formula. Sample size for each group was $21+$ $10 \%$ (loss of follow up/drop out $)=23 \approx 25$ subjects. Total sample was 50 subjects.

In a double-blind, placebo-controlled, clinical trial, subjects were randomly received vitamin D 50,000 IU/ week or placebo treatment continuously for 10 weeks. They received 3 capsules for oral use containing 50,000 IU (Natrol $\left.{ }^{\circledR} 10,000 \mathrm{IU}\right)$ of vitamin $\mathrm{D}_{3}$ taken weekly or placebo with the same weight as vitamin D supplementation. The selection of treatment group was done randomly using random table, which was done by others. Both subjects and researcher did not know whether the subject got a placebo or vitamin D supplementation. Twenty-five subjects had placebo and 25 subjects had vitamin D supplementation. The two groups of subjects were treated in parallel.

The inclusion criteria were cooperative of T2DM subjects with mild - moderate DPN and approved to follow the study. The exclusion criteria were subjects that consumed vitamin D in the last 3 months, were taking anti-tuberculous drugs or chemotherapy, with renal, hepatic, gastrointestinal, stroke, malignancy or infection problems, pregnant, breastfeeding, or using oral contraceptives. Finally, subjects who had allergy of vitamin $\mathrm{D}$ and did not regularly take medication were excluded from this study.

Before and 10 weeks after treatment, blood sample were collected to determine the serum concentration of biomarkers: Hemoglobin A1c (HbA1c) was measured with enzyme immunoassay method by D-10. Vitamin D levels or 25-hydroxyvitamin D $(25(\mathrm{OH}) \mathrm{D})$ was measured with chemiluminescent immunoassay method by DiaSorin Liaison and AR was measured with enzyme-linked immunosorbent assay method by Assaypro LLC. At first and at the end of the study, NCV were evaluated by the same neurologist using Cadwell ENMG (electroneuromyography) machine.

The primary endpoint was the mean changes in $\mathrm{AR}$ and vitamin $25(\mathrm{OH}) \mathrm{D}$ levels and $\mathrm{NCV}$, which was compared between treatment groups. The result indicates that there was difference mean between two groups, using Independent $\mathrm{T}$ test. The correlation of mean changes was analysed using Pearson correlation. The role of AR on NCV was analysed using Linear Regression. The results were considered significant at $p<0.05$. Coefficient $r$ measures the strength level and direction of correlation. Negative (-) or positive $(+)$ sign indicate correlation have negative or positive relationship, while the number indicates the level of correlation. $r$ less or equal to 0.3 , means weak correlation. $r$ value between 0.3 and 0.7 means moderate correlation, while $r$ more than 0.7 means strong correlation. The statistical calculations were done using SPSS version 23. The flow diagram of this study as shown in Figure 1.

\section{RESULTS AND DISCUSSION}

This study included a total of 50 subjects. Characteristics of the study samples are presented in Table 1. The subjects were mostly female, middle to old age, have been suffering of DM for more than 5 years, no smoking, and had metabolic syndrome. The majority used only one anti-diabetic and oral medication. Their characteristics were similar in both groups at baseline $(\mathrm{p}>0.05)$. 


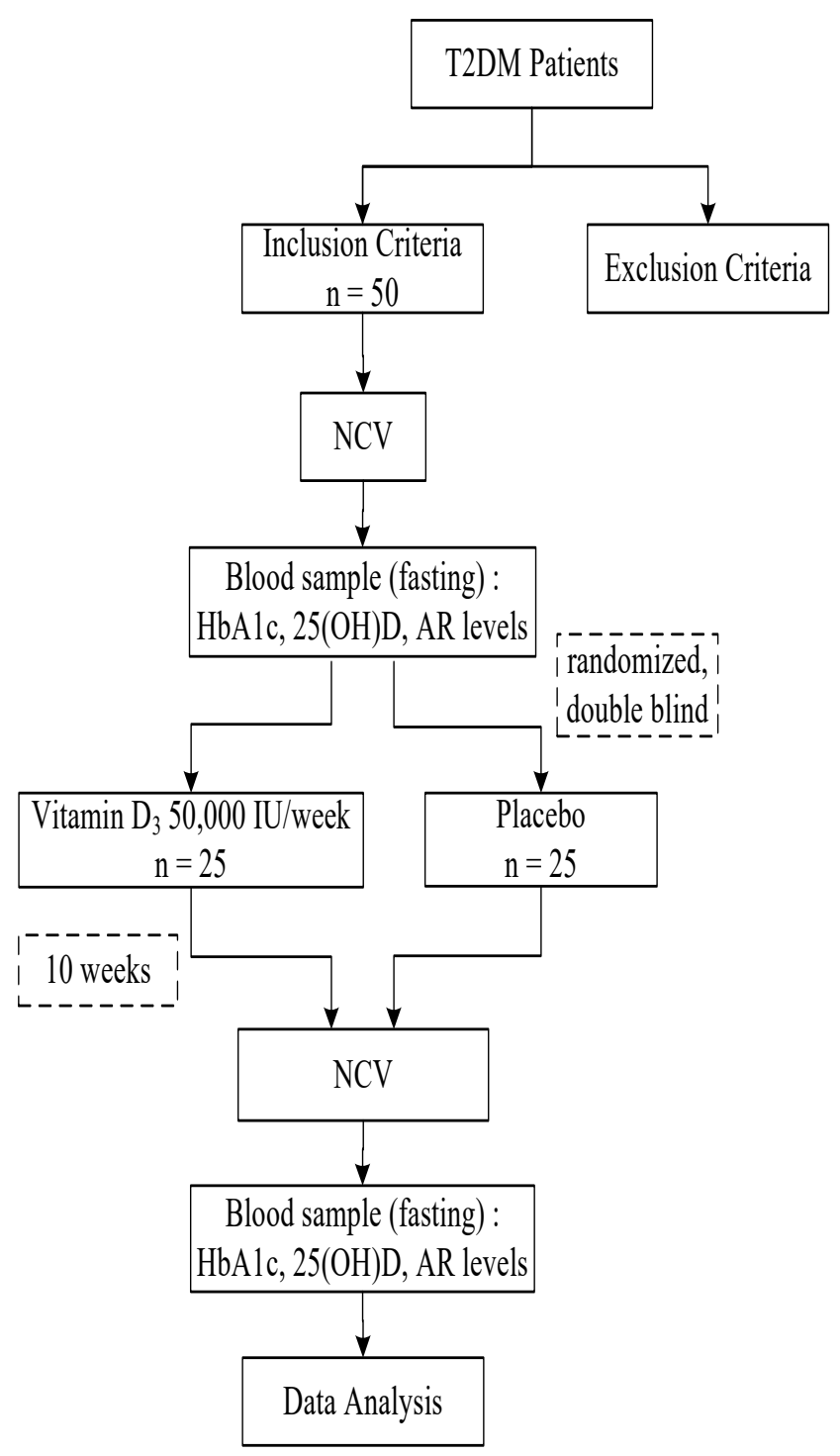

FIGURE 1. The flow diagram of the study

In Table 1, all subjects had mean HbAlc level $>6.5 \%$. Level of $\mathrm{HbA} 1 \mathrm{c}>6.5 \%$ has a 16.9 times risk of developing neuropathy. $\mathrm{HbA} 1 \mathrm{c}$ level is the strongest predictor of DN (Nisar et al. 2015). All of them had vitamin D deficiency $(<20 \mathrm{ng} / \mathrm{mL})$. A systematic review and meta-analysis of 1484 T2DM patients showed a significant association (odds ratio 2.68 ) between vitamin $\mathrm{D}$ deficiency and the development of DPN (Basit et al. 2016).

In this study, there were no significant mean changes in HbAlc and AR levels between vitamin D and placebo groups after treatment (Table 2). Vitamin D supplementation had no effect on mean changes of HbAlc and AR levels. Evidence that vitamin D can improve glycemic control in DM patients is still mixed (Christie-David et al. 2015). Based on a systematic review by Mitri and Pittas (2014), majority of the studies with T2DM subjects, vitamin D supplementation had no effect on glycemic control after 8-26 weeks' period.

In Table 2, mean changes of $25(\mathrm{OH}) \mathrm{D}$ level was higher in vitamin D than placebo groups. Vitamin D supplementation at dose of 30,000 IU/week resulted in an increase in vitamin 25(OH)D levels of 2.26-2.92 $\mathrm{ng} /$ week for the first 8 weeks and followed by a slight increase of 1.64-1.73 ng/week over a range of 12 weeks (Toth et al. 2017). 
In this study, there were no significant correlation between mean changes of HbAlc and AR levels (Table $3)$. Aldose reductase had no effect on HbAlc level. There was no significant correlation between changes in vitamin 25(OH)D and AR levels (Table 3). Study of Derakhshanian et al. (2019) in diabetic rats, vitamin D did not affect the expression of AR to prevent diabetic nephropathy. Although AR is the main enzyme in the polyol pathway. Schwann cells de-differentiate into immature cells under conditions of hyperglycemia, as a result of sorbitol accumulation and decreased insulin like growth factor 1 (Igf1) expression. In vitro, Schwann cell de-differentiation can be re-differentiated into mature cells by administering AR inhibitors to reduce levels of sorbitol and vitamin $\mathrm{D}_{3}$ to increase Igf1 expression. In mouse models, vitamin $\mathrm{D}_{3}$ can cause re-differentiation of schwann cells, even though sorbitol levels are still high (Hao et al. 2015).

There was significant correlation with negative direction and weak correlation between mean changes of AR level and NCV of motor tibial nerve (Table 4). In transgenic mice with excessive AR expression, an increase in the accumulation of sorbitol and fructose was found along with a decrease in NCV of motor Tibial nerve (Yagihashi et al. 2001). In mouse models, very high AR messenger RNA (mRNA) is expressed in the main target organs of DM complications, namely the lens, retina, and sciatic nerve (Badria et al. 2017). The tibial nerve is a branch of the sciatic nerve.

Increased expression or activity of AR in DM results in retinopathy, neuropathy, nephropathy, and angiopathy (Derakhshanian et al. 2019). Streptozotocin induction causes DPN after 4 weeks, by observing neurophysiological and morphological changes in nerves. In rat studies, AR and poly (ADP-ribose) polymerase (PARP) activity increased significantly 4 weeks after diabetes induction and continued over time. High AR is expressed in Schwann cells (Ariza et al. 2014). Schwann cells play an important role in regulating peripheral nerve function and NCV (Hao et al. 2015).

TABLE 1. Characteristics of PND patients

\begin{tabular}{|c|c|c|c|c|c|c|}
\hline \multirow{2}{*}{ Characteristics } & \multicolumn{2}{|c|}{ Vitamin D $(n=25)$} & \multicolumn{2}{|c|}{ Placebo $(n=25)$} & \multirow[t]{2}{*}{$\mathrm{p}$} & \\
\hline & frequency & $\%$ & frequency & $\%$ & & \\
\hline Gender & & & & & $0.111^{\mathrm{a}}$ & \\
\hline Male & 4 & 16 & 9 & 36 & & \\
\hline Female & 21 & 84 & 16 & 64 & & \\
\hline Smoking status & & & & & $1.000^{\mathrm{a}}$ & \\
\hline Yes & 3 & 12 & 3 & 12 & & \\
\hline No & 22 & 88 & 22 & 88 & & \\
\hline Number of anti-diabetic drug & & & & & $0.696^{\mathrm{a}}$ & \\
\hline 1 & 15 & 60 & 13 & 52 & & \\
\hline$>1$ & 10 & 40 & 12 & 48 & & \\
\hline Type of anti-diabetic & & & & & $0.852^{\mathrm{a}}$ & \\
\hline Insulin & 11 & 44 & 10 & 40 & & \\
\hline Oral medication & 14 & 56 & 13 & 52 & & \\
\hline Oral medication and Insulin & 0 & 0 & 2 & 8 & & \\
\hline Metabolic Syndrome & & & & & $0.243^{\mathrm{a}}$ & \\
\hline Yes & 14 & 56 & 18 & 72 & & \\
\hline No & 11 & 44 & 7 & 28 & & \\
\hline \multirow[t]{2}{*}{ Characteristics } & \multicolumn{2}{|c|}{ Vitamin D $(n=25)$} & \multicolumn{3}{|c|}{ Placebo $(n=25)$} & \\
\hline & \multicolumn{2}{|c|}{ Mean \pm SD } & \multicolumn{2}{|c|}{ Mean \pm SD } & & $P$ \\
\hline Age (years) & \multicolumn{2}{|c|}{$54.56 \pm 7.15$} & \multicolumn{2}{|c|}{$58.20 \pm 9.46$} & & $0.232^{\mathrm{b}}$ \\
\hline Duration of DM (years) & \multicolumn{2}{|c|}{$6.06 \pm 6.23$} & \multicolumn{2}{|c|}{$6.78 \pm 5.86$} & & $0.539^{\mathrm{b}}$ \\
\hline HbA1c Level at Baseline (\%) & \multicolumn{2}{|c|}{$9.26 \pm 2.70$} & \multicolumn{2}{|c|}{$8.30 \pm 1.54$} & & $0.130^{\mathrm{b}}$ \\
\hline 25(OH)D Level at Baseline $(\mathrm{ng} / \mathrm{mL})$ & \multicolumn{2}{|c|}{$16.03 \pm 5.02$} & \multicolumn{2}{|c|}{$18.52 \pm 5.17$} & & $0.091^{\mathrm{b}}$ \\
\hline
\end{tabular}

${ }^{\mathrm{a} C h i-S q u a r e ~ T e s t ;}{ }^{\mathrm{b}}$ Independent T Test, ${ }^{*} \mathrm{p}<0.05$ 
In our study, there were no significant correlation between changes of AR levels and NCV of other nerves. Hypothetically this is because of the mean diabetes duration less than 10 years thus not many nerves were involved. This will require further study to get a firm conclusion.

There was significant correlation with positive direction and moderate strength between mean changes of 25(OH)D level and NCV of motor Median and Peroneal nerves, and motor and sensory Ulnar nerves (Table 4). Based on the study of Ariza et al. (2014), sensory nerves are more susceptible to hyperglycemia than motor nerves. At 4 weeks after induction of streptozotocin, NCV of sensory nerves decrease by $15-$ $20 \%$. There were no significant changes in NCV of motor nerves, although that tend to decrease especially after 8 weeks. The amplitudes of the motor and sensory nerves do not show any significant changes. High glucose level induces a significant decrease in myelin fibers, but not in axon diameter. The decrease of NCV is related to a decrease in the size of fibers and myelin thickness (Ariza et al. 2014). Smaller amplitude reflects axonal loss and slowing of NCV is the result of a combination of segmental demyelination, loss of fastest axon conduction, and metabolic changes (Agarwal et al. 2018).

Animal studies indicate that vitamin D was efficient at protecting neurons, reducing toxicity, and neuronal damage. Vitamin D has an antioxidant effect and prevents neuronal necrosis by decreasing the release of free radicals and inhibiting calcium channels. Vitamin D prevents the degradation of nerve growth factor, thus, effectively treating a number of neurodegenerative and neuroinflammatory diseases by activating myelinrelated genes, accelerating myelination and recovery (Demiryurek \& Gundogdu 2017).

TABLE 2. Difference of mean changes in $\mathrm{HbA1c}, 25(\mathrm{OH}) \mathrm{D}$, and AR levels between vitamin $\mathrm{D}$ and placebo groups after supplementation

\begin{tabular}{lccc}
\hline \multicolumn{1}{c}{ Variables } & Vitamin D & Placebo & $\mathrm{p}$ \\
\hline Levels & & & 0.192 \\
$\mathrm{HbA1c}(\%)$ & $-0.48 \pm 2.56$ & $0.32 \pm 1.73$ & $0.001^{*}$ \\
$25(\mathrm{OH}) \mathrm{D}(\mathrm{ng} / \mathrm{mL})$ & $19.98 \pm 11.20$ & $1.80 \pm 10.00$ & 0.477 \\
$\mathrm{AR}(\mathrm{ng} / \mathrm{mL})$ & $0.01 \pm 3.25$ & $0.61 \pm 2.71$ & \\
\hline
\end{tabular}

Independent $\mathrm{T}$ Test; $* \mathrm{p}<0.05$

TABLE 3. Correlation of mean changes in $\mathrm{HbA1c}$ and 25(OH)D with AR levels

\begin{tabular}{lcc}
\hline & Variables & $\mathrm{AR}$ \\
\cline { 2 - 3 } & $\mathrm{r}$ & $\mathrm{p}$ \\
\hline Levels & & \\
HbA1c $(\%)$ & 0.201 & 0.161 \\
$25(\mathrm{OH}) \mathrm{D}(\mathrm{ng} / \mathrm{mL})$ & 0.013 & 0.929 \\
\hline
\end{tabular}

Pearson Correlation Test; $\mathrm{p}<0.05$

TABLE 4. Correlation of mean changes in AR and 25(OH)D levels with NCVs

\begin{tabular}{lcccc}
\hline \multirow{2}{*}{ Nerve Conduction Velocities $(\mathrm{m} / \mathrm{s})$} & \multicolumn{2}{c}{$\mathrm{AR}$} & \multicolumn{2}{c}{$25(\mathrm{OH}) \mathrm{D}$} \\
\cline { 2 - 5 } & $\mathrm{r}$ & $\mathrm{p}$ & $\mathrm{r}$ & $\mathrm{p}$ \\
\hline Motor Median & 0.113 & 0.433 & 0.525 & $<0.001^{* *}$ \\
Motor Ulnar & -0.044 & 0.761 & 0.438 & $0.001^{*}$ \\
Sensory Median & -0.176 & 0.222 & 0.257 & 0.072 \\
Sensory Ulnar & 0.010 & 0.947 & 0.527 & $<0.001^{* *}$ \\
Motor Peroneal & 0.029 & 0.843 & 0.494 & $<0.001^{* *}$ \\
Motor Tibial & -0.337 & $0.017^{*}$ & 0.235 & 0.101 \\
Sensory Sural & -0.240 & 0.093 & 0.231 & 0.106 \\
\hline
\end{tabular}

Pearson Correlation Test, ${ }^{*} \mathrm{p}<0.05 ; * * \mathrm{p}<0.001$ 


\section{CONCLUSION}

In conclusion, vitamin $\mathrm{D}$ supplementation had no effect on AR level in Indonesian DPN patients. Higher AR level was correlated with decreased NCV of motor Tibial nerve. Vitamin D supplementation improved NCVs in DPN.

\section{ACKNOWLEDGEMENTS}

There are no conflicts of interest. No funding.

\section{REFERENCES}

Agarwal, S., Lukhmana, S., Kahlon, N., Malik, P. \& Nandini, H. 2018. Nerve conduction study in neurologically asymptomatic diabetic patients and correlation with glycosylated hemoglobin and duration of diabetes. National Journal of Physiology, Pharmacy and Pharmacology 8(11): 1533-1538.

Ariza, L., Pagès, G., Garcia-Lareu, B., Cobianchi, S., Otaegui, P.J., Ruberte, J., Chillón, M., Navarro, X. \& Bosch, A. 2014. Experimental diabetes in neonatal mice induces early peripheral sensorimotor neuropathy. Neuroscience 274: 250-259.

Badria, F.A., Elimam, D.M., Elabshihy, M.S. \& Ibrahim, A.S. 2017. Aldose reductase inhibitors from nature: A new hope for treatment of cataract. JOJ Ophthal. 5(1): 555655.

Basit, A., Basit, K.A., Fawwad, A., Shaheen, F., Fatima, N., Petropoulos, I.N., Alam, U. \& Malik, R.A. 2016. Vitamin D for the treatment of painful diabetic neuropathy. BMJ Open Diabetes Research and Care 4(1): e000148.

Christie-David, D.J., Girgis, C.M. \& Gunton, J.E. 2015. Effects of vitamin C and D in type 2 diabetes mellitus. Nutrition and Dietary Supplements 7: 21-28.

Demiryurek, B.E. \& Gundogdu, A.A. 2017. The effect of vitamin D levels on pain in carpal tunnel syndrome. Orthopaedics \& Traumatology: Surgery \& Research 103(6): 919-922.

Derakhshanian, H., Djazayery, A., Javanbakht, M.H., Eshraghian, M.R., Mirshafiey, A., Zarei, M., Alvandi, E., Djalali, E. \& Djalali, M. 2019. The effect of vitamin D on cellular pathways of diabetic nephropathy. Reports of Biochemistry \& Molecular Biology 7(2): 217-222.

Gupta, S., Maratha, A., Siednienko, J., Natarajan, A., Gajanayake, T., Hoashi, S. \& Miggin, S. 2017. Analysis of inflammatory cytokine and TLR expression levels in type 2 diabetes with complications. Scientific Reports 7: 7633.

Hao, W., Tashiro, S., Hasegawa, T., Sato, Y., Kobayashi, T., Tando, T., Katsuyama, E., Fujie, A., Watanabe, R., Morita, M. \& Miyamoto, K. 2015. Hyperglycaemia promotes Schwann cell de-differentiation and de-myelination via sorbitol accumulation and Igf1 downregulation. The Journal of Biological Chemistry 290(28): 17106-17115.

Kakrani, A.L., Gokhale, V.S., Vohra, K.V. \& Chaudhary, N. 2014. Clinical and nerve conduction study correlation in patients of diabetic neuropathy. The Journal of the Association of Physicians of India 62(1): 24-27.

Kawano, T. 2014. A current overview of diabetic neuropathymechanisms, symptoms, diagnosis, and treatment. Peripheral Neuropathy 10: 89-105.

Kumar, B.J.P., Itaggappa, M. \& Thimmaraju, K.V. 2017. Association of vitamin D deficiency with oxidative stress in newly diagnosed type 2 diabetes. International Journal of Research in Medical Sciences 5(12): 5221-5226.

Mitri, J. \& Pittas, A.G. 2014. Vitamin D and diabetes. Endocrinology and Metabolism Clinics of North America 43(1): 205-232.

Nisar, M.U., Asad, A., Waqas, A., Ali, N., Nisar, A., Qayyum, M.A., Maryam, H., Javaid, M. \& Jamil, M. 2015. Association of diabetic neuropathy with duration of type 2 diabetes and glycemic control. Cureus 7(8): e302.

Oyenihi, A.B., Ayeleso, A.O., Mukwevho, E. \& Masola, B. 2015. Antioxidant strategies in the management of diabetic neuropathy. BioMed Research International 2015: 515042.

Pop-Busui, R., Boulton, A.J., Feldman, E.L., Bril, V., Freeman, R., Malik, R.A., Sosenko, J.M. \& Ziegler, D. 2017. Diabetic neuropathy: A position statement by the American Diabetes Association. Diabetes Care 40(1): 136-154.

Ramana, K.V. 2011. Aldose reductase: New insights for an old enzyme. Biomolecular Concepts 2(1-2): 103-114.

Santos, G.C., Zeidler, J.D., Pérez-Valencia, J.A., Sant'AnnaSilva, A.C.B., Da Poian, A.T., El-Bacha, T. \& Almeida, F.C.L. 2017. Metabolomic analysis reveals vitamin D-induced decrease in polyol pathway and subtle modulation of glycolisis in HEK293T cells. Scientific Reports 7(1): 9510.

Shekharappa, K.R., Srinivas, A.K., Vedavathi, K.J. \& Venkatesh, G.A. 2011. A study on the utility of nerve conduction studies in type 2 diabetes mellitus. Journal of Clinical and Diagnostic Research 5(3): 529-531.

Tang, W.H., Martin, K.A. \& Hwa, J. 2012. Aldose reductase, oxidative stress, and diabetic mellitus. Frontiers in Pharmacology 3: 87.

Toth, B.E., Takacs, I., Szekeres, L., Szabo, B., Bakos, B. \& Lakatos, P. 2017. Safety and efficacy of weekly 30,000 iu vitamin D supplementation as a slower loading dose administration compared to a daily maintenance schedule in deficient patients: A randomized, controlled clinical trial. Journal of Pharmacovigilance 5: 4.

Yagihashi, S., Yamagishi, S.I., Wada Ri, R., Baba, M., Hohman, T.C., Yabe-Nishimura, C. \& Kokai, Y. 2001. Neuropathy in diabetic mice overexpressing human aldose reductase and effects of aldose reductase inhibitor. Brain 124(Pt 12): 2448-2458.

Yan, M.K.W. \& Khalil, H. 2017. Vitamin supplements in type 2 diabetes mellitus management: A review. Diabetes \& Metabolic Syndrome 11(Suppl 2): S589-S595.

Zhu, C. 2013. Aldose reductase inhibitors as potential therapeutic drugs of diabetic complications. In Diabetes Mellitus-Insights and Perspectives, edited by Oguntibeju, O.O. Rijeka, Croatia: IntechOpen. pp. 17-46. 
Aida Fitri* \& Hasan Sjahrir

Department of Neurology, Faculty of Medicine Universitas Sumatera Utara

No. 5 Dr. Mansyur Road Medan

20155 North Sumatera

Indonesia

Adang Bachtiar

Faculty of Public Health

University of Indonesia

Lingkar Kampus Raya

Universitas Indonesia

Road Depok 16424

Indonesia
Muhammad Ichwan

Department of Pharmacology and Therapeutic

Faculty of Medicine

Universitas Sumatera Utara

No. 5 Dr. Mansyur Road Medan

20155 North Sumatera

Indonesia

*Corresponding author; email: aida.fithrie@gmail.com

Received: 17 September 2019

Accepted: 19 April 2021 